\title{
Documented records of Gaidropsarus granti (Osteichthyes: Lotidae) in the Adriatic Sea and review of its Mediterranean occurrences: is it a native fish or a newly established one?
}

\author{
Giambattista BELLO \\ Arion, Via Colombo 34, 70042 Mola di Bari, Italy \\ Corresponding author, e-mail: giamb.bello@gmail.com
}

\begin{abstract}
Gaidropsarus granti (Osteichthyes: Lotidae) is a rare fish that was recorded for the first time in the Mediterranean Sea in 1989. The Mediterranean records have been documented for the Ligurian Sea, the Levant Sea close to Rhodes, off the Sardinian coasts and for the northern Ionian Sea south of the Straits of Messina. Additional reports referred its presence in the Alboran Sea, in the southern Adriatic Sea and west of Malta, though without any additional information. The present paper reports the occurrence of $\mathrm{G}$. granti in the Adriatic Sea (eastern Mediterranean) thanks to the examination of eight specimens collected in its south-western part, between February 1997 and October 2017. Six of them had been trawled at depths from 190 to $290 \mathrm{~m}$, mainly in a channel within coral banks, while two were caught by hook at $420 \mathrm{~m}$ depth on coral banks. Their total length ranged from 21.0 to $32.3 \mathrm{~cm}$. Four dissected individuals were adult, three males and one female. The stomach of two individuals contained only galatheid shrimps of the genus Munida, some of which were identified as M. rutllanti. According to interviews with fishermen based in the area where G. granti specimens were trawled, this conspicuous fish was unknown to them until the 1997 captures. Afterwards, it became well known to all of them, because few specimens are presently caught every once in a while. It is discussed whether G. granti is a native Mediterranean species or a fish that entered this sea a few decades ago. Both hypotheses have some support. The autochthonous origin hypothesis is mainly based on both $\mathrm{G}$. granti distribution throughout the Mediterranean and its unavailability to old fishing gear uncapable of fishing on deep, rough grounds. The contrasting allochthonous hypothesis is backed by the total lack of Mediterranean records prior to 1989 coupled with its quite long larval pelagic phase.
\end{abstract}

Key words: Gaidropsarus granti, Lotidae, Adriatic Sea, Mediterranean, new records

\section{INTRODUCTION}

The Grant's rockling, alias Azorean alias leopard rockling, Gaidropsarus granti (Regan, 1903) (Osteichthyes: Lotidae), is a rare fish from the eastern Atlantic Ocean. Seemingly, only four specimens of this species had been recorded worldwide until 1995, all of them in a 15 years span at the turn of the XX century. The first one, from the Canary Islands, was reported by STEINDACHNER (1891), who did not realize that it was a new species and ascribed it to Motella (= Gaidropsarus) guttatus Collett, 1890. Two specimens, collected nearby the 
Azores, were recognized as a new species and named Onus granti by REGAN (1903). Lastly, COLLETT (1905) described a fourth specimen, from the Azores, and mistakenly ascribed it to Gaidropsarus guttatus.

A revision of the genera Antonogadus, Gaidropsarus and Onogadus - all of them presently in the genus Gaidropsarus - was prepared by WHEELER, but never published because of his death. Some of his results were reported in SVETOVIDOV (1973). WHEELER in SVETOVIDOV (1973) and SVETOVIDOV (1986) recorded only the occurrences reported hereabove from the geographic range of the Canary Islands and the Azores; incidentally, SVETOVIDOV (1986) erroneously stated that only one specimen was described by REGAN (1903). No additional finds were listed by COHEN et al. (1990).

After 90 years of record void, an individual of G. granti collected in 1995 in the Levant Sea close to Rhodes was described by ZACHARIOUMAMALINGA (1999). More finds were reported in the following years from both the north-eastern Atlantic Ocean - one specimen from Lanzarote,
Canary Archipelago (BRITO et al., 2002), two from Galician waters (BAÑÓN et al., 2010), several from Azores (MENEZES et al., 2009; ORSI RELINI \& RELINI, 2014; GARCIA, 2015) - and the Mediterranean Sea (summarized in Fig. 1). Most of the G. granti records are listed in GARCIA (2015). In summary, the occurrences of nine individuals have been documented in the Mediterranean Sea, six from the western and three from the eastern basin.

The alternative hypotheses whether G. granti is a native Mediterranean fish or an Atlantic one that recently entered this basin through the Gibraltar Strait have been much debated in the last ten years (ZACHARIOU-MAMALINGA, 1999; GOLANI et al., 2002 and subsequent updates; MURA \& CAU, 2003; CORSINI-FOKA \& ECONOMIDIS, 2007; PAIS et al., 2008; ZENETOS et al., 2009; ORSI RELINI \& RELINI, 2014; TIRALONGO \& RUSSO, 2015; SPINELLI \& CASTRIOTA, pers. comm.).

This paper deals with the finds of eight specimens of G. granti collected in the south-western Adriatic Sea (eastern Mediterranean), from 1997 to 2014, which represent the first documented

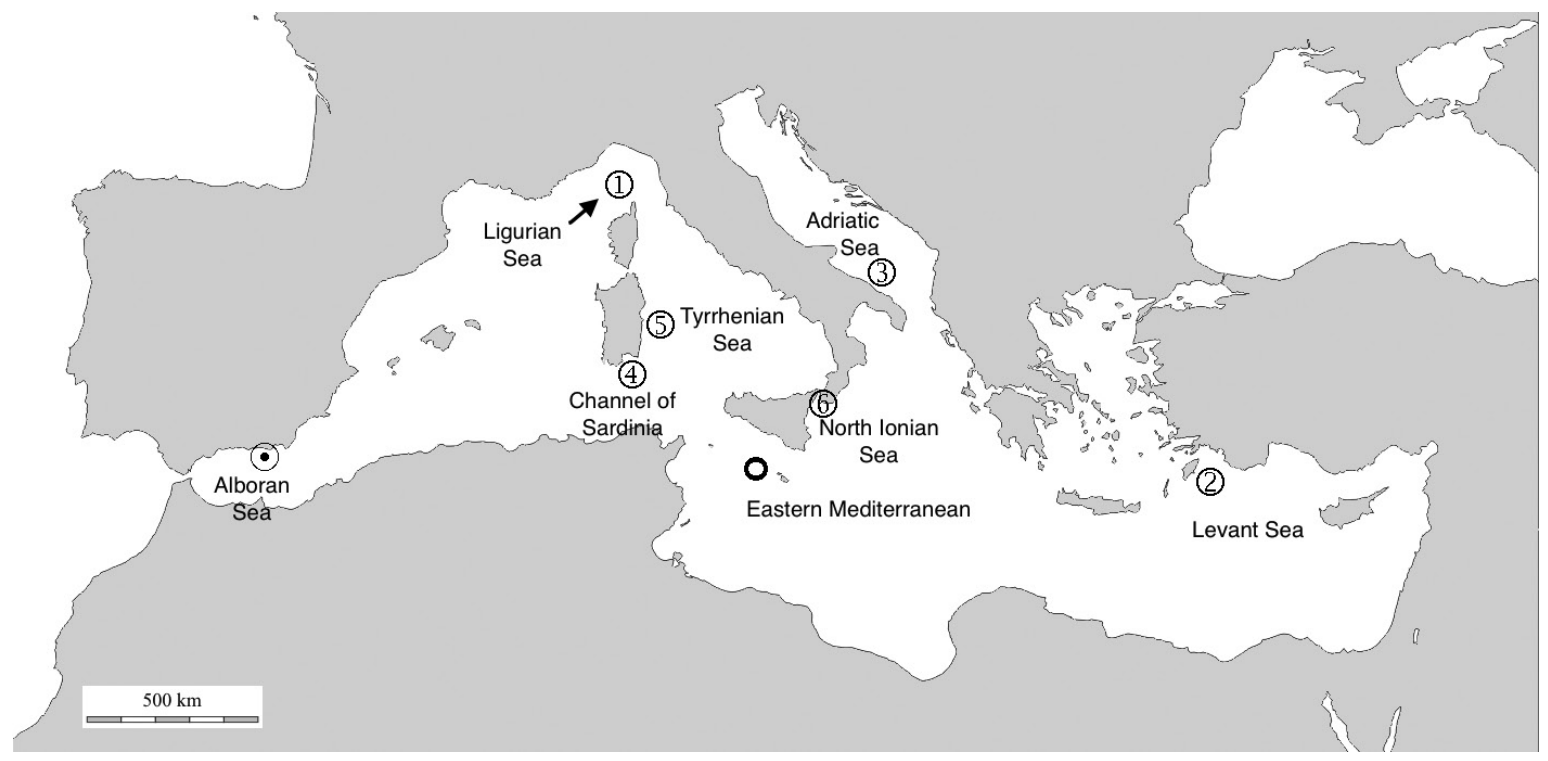

Fig. 1. Mediterranean sites of Gaidropsarus granti findings. Documented reports numbered in chronological order of occurrence: (1) = 1989-90, Ligurian Sea (three specimens; ORSI RELINI \& RELINI, 2014); (2) = 1995, SE of Rhodes (one; ZACHARIOU-MAMALINGA, 1999); (3) = 1997-2017, SW Adriatic Sea (eight; present results); (4) = 2000, Sof Sardinia (one; MURA \& CAU, 2003); (5) = 2007, E of Sardinia (one; PAIS et al., 2008); (6) = 2014, off Calabria S of Messina Strait (one; ANONYMOUS - photo by Carmelo Infortuna, 2014 and TIRALONGO \& RUSSO, 2015) and 2016, off Calabria S of Messina Strait (two; CASTRIOTA \& SPINELLI, 2018). Undocumented finds: $\mathbf{O}=1991, \mathrm{~W}$ of Malta (ANDALORO et al., 2011); same site as documented finds (3): 2010 (one specimen; BO et al., 2012 and ANGELETTI et al., 2014); $\odot=$ between 2006 and 2013, Chella Bank (one; AGUILAR et al., 2013) 
record (sensu BELLO et al., 2014) in this sea. Seemingly, it was never collected before in that district (see negative evidence in BELLO \& RIZZI, 1988) nor reported from any other part of the Adriatic Sea (LIPEJ \& DULČIĆ, 2010). Indeed, both BO et al. (2012) and ANGELETTI et al. (2014) refer the same observation of an individual of $G$. granti detected by ROV in the Bari canyon, S-W Adriatic Sea, in 2010, but neither paper documents it in any way. The present is also the most copious account of this rare lotid fish in just one Mediterranean district. Incidentally, FishBase does not report the southern Adriatic Sea in the suitable habitat map for G. granti (LUNA \& AUGUSTIN, 2017).

Moreover, this paper thoroughly analyses and discusses the above-reported alternative hypotheses of the Mediterranean presence of $G$. granti.

\section{MATERIAL AND METHODS}

The eight specimens of Gaidropsarus granti herein accounted for were caught in the southwestern Adriatic Sea, off Mola di Bari, by fishermen based in that town harbour during regular commercial fishing operations. Six of them were netted by bottom trawling, mostly in the Bari canyon, from 1997 to 2014; the other two were captured by bottom longline on coral banks, in 2017. The capture data are given in Table 1 .

The fish specimens were identified with the help of FNAM handbook (SVETOVIDOV, 1986).
In the laboratory, measurements and meristic counts of specimens of $G$. granti were obtained according to standard procedures: total length (TL), body mass without stomach contents mass (W), body height above anus $(\mathrm{BH})$; rays in second dorsal fin (II D), rays in anal fin (A), rays in pectoral fins $(\mathrm{P})$. The number of rays in those fins is an important feature for taxonomic discrimination between the species in the genus Gaidropsarus (SVETOVIDOV, 1986). The regression equation correlating $\mathrm{W}$ to $\mathrm{TL}$ was computed. Gonads were examined and their maturity stage was assessed according to HOLDEN \& RAITT (1974). The stomach contents of all specimens except for nos. 2 and 4 were examined and prey items identified to the lowest possible taxon; crustaceans were identified by means of ZARIQUIEY ALVAREZ (1968). Afterwards, the fishes were preserved in 10\% formalin apart from no. 6 , which was preserved in $75 \%$ ethanol and deposited in the Zoology Museum of the University of Bari (accession number: MUZAC 6313).

In the days following the find of the first two G. granti specimens (February 1997), many trawl fishermen from Mola di Bari and neighbouring harbour towns were interviewed with photos of the fish shown to them. Additional interviews were carried out after the acquisition of specimen nos. 5 (January 2010) and 6 (August 2014), as well as during the preparation of this paper. Only fully reliable fishermen were interviewed on the latter occasions.

Table 1. Data for Gaidropsarus granti collected in the south-western Adriatic Sea. Specimens 1-6 caught by trawl net, 7 and 8 by bottom longline. Notes: (a) specimen no. 2 already dressed and cut into pieces by fishmonger when examined by the present author; comparable in size to sp. no. 1; (b) identified by external features only and approximatively measured (specimen already sold when noticed by the present author in the fish market)

\begin{tabular}{|l|l|l|l|l|}
\hline Specimen no. & Date of collection & Depth $(\mathrm{m})$ & Type of bottom & Notes \\
\hline 1 and 2 & 11 Februay 1997 & 190 & rough & a \\
3 & 10 October 1997 & 270 & channel within coral banks: Bari canyon \\
4 & channel within coral banks: Bari canyon & bctober 1997 & 270 & channel within coral banks: Bari canyon \\
5 & 7 January 2010 & 290 & channel within coral banks: Bari canyon & \\
6 & 1 August 2014 & $240-260$ & coral banks & \\
7 and 8 & 22 October 2017 & 420 &
\end{tabular}




\section{RESULTS}

\section{Fish examination}

Measurements, meristic counts, sex, maturity stage and stomach contents of the examined 6 specimens are reported in Table 2. They ranged in total length from 21.0 to $32.3 \mathrm{~cm}$ (mean = $27.6 \mathrm{~cm}$ ) and in body mass from 65.0 to 214.3 $\mathrm{g}($ mean $=150.3 \mathrm{~g})$. The regression equation correlating body mass to total length was $\mathrm{W}=$ $8.320 \times 10^{-3} \mathrm{TL}^{2.934} ; \mathrm{n}=6$; $\mathrm{r}=0.994$ (Fig. 2).

The fin ray counts showed a limited variability; ranges and most frequent counts (in bold) were 58-59-60 rays for the second dorsal (II D), 48-49 for the anal (A), 20-21-22 for the pectoral (P) fins.

The body height index, $\mathrm{BH} / \mathrm{TL}$, ranged from 13.3 to $14.0 \%$, mean $=13.8 \%$.

The specimens were dark red-brownish dorso-laterally, with longitudinal wavy white stripes delineating coloured bands and spots; pink to white ventro-laterally (Fig. 3). The pattern of dark-coloured parts differed from one fish to another. The colouration of the Adriatic specimens matched perfectly with the quite long and detailed description provided by REGAN (1903) and with the accurate account by ORSI RELINI \& RELINI (2014).

Three of the dissected specimens were males, one was female and two indeterminate. It was not clear whether the three smallest individuals $(\mathrm{TL}=21.0-24.5 \mathrm{~cm})$ were spent or immature. It

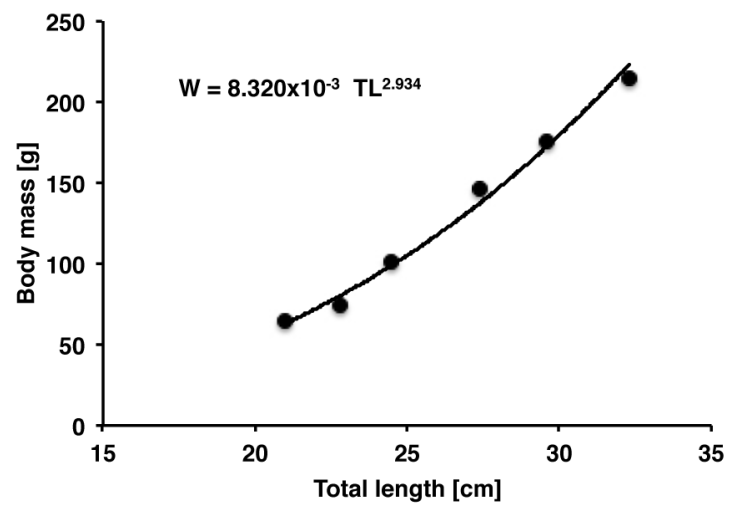

Fig. 2. Body mass/total length regression equation (power type) for Gaidropsarus granti specimens collected in the south-western Adriatic Sea

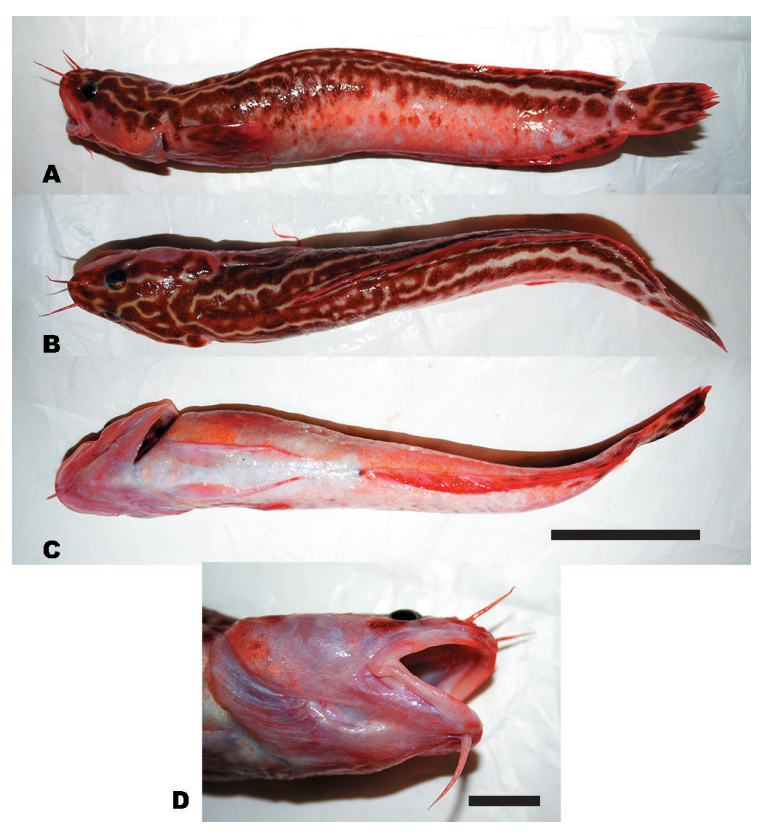

Fig. 3. Specimen of Gaidropsarus granti collected in the south-western Adriatic Sea, off Mola di Bari, in January 2010. Sex = male; total length $=27.4 \mathrm{~cm}$. A) side view; B) dorsal view; C) ventral view; D) close-up of the head (vomerini teeth, snout and chin barbels visible). Scale bars $=5 \mathrm{~cm}(A, B, C)$ and $1 \mathrm{~cm}(D)$

seems that maturing is in winter-spring period and spawning in summer. The stomachs of three specimens contained only galatheid shrimps of the genus Munida (Anomura: Galatheidae) at an early digestion stage (Table 2); the other three were empty.

\section{Interviews}

The first two specimens of Gaidropsarus granti from the south-western Adriatic Sea (February 1997) immediately attracted the attention of their capturer because of their very noticeable and beautiful colouration. This unique colour pattern set them apart from the three known Mediterranean three-bearded rocklings, namely Gaidropsarus biscayensis (Collet, 1890), Gaidropsarus mediterraneus (Linnaeus, 1758) and Gaidropsarus vulgaris (Cloquet, 1824), all of which inhabit the southern Adriatic Sea (RELINI \& LANTERI, 2010) and are familiar to fishermen. According to the interviews carried out shortly after the first G. granti capture (February 1997), no trawl fisherman had ever seen that fish species before. On the contrary, the fishermen inter- 
Table 2. Measurements, meristic counts, sex, maturity stage and stomach contents of six specimens of Gaidropsarus granti collected in the south-western Adriatic Sea. Specimen numeration as in Table 1. TL = total length, $W=$ body mass less stomach contents, $B H=$ body height above anus; $I I D=$ rays in second dorsal fin, $A=$ rays in anal fin, $P=$ rays in pectoral fins

\begin{tabular}{|c|c|c|c|c|c|c|c|c|c|c|}
\hline $\begin{array}{c}\text { Specimen } \\
\text { no. }\end{array}$ & $\begin{array}{c}\text { Date of } \\
\text { collection }\end{array}$ & $\begin{array}{c}\text { TL } \\
(\mathrm{cm})\end{array}$ & $\begin{array}{c}\mathrm{W} \\
(\mathrm{g})\end{array}$ & $\begin{array}{c}\mathrm{BH} \\
(\mathrm{cm})\end{array}$ & II D & $\mathrm{A}$ & $\mathrm{P}$ & Sex & $\begin{array}{c}\text { Maturity } \\
\text { stage }\end{array}$ & $\begin{array}{c}\text { Stomach contens } \\
\text { (quantity of food items) }\end{array}$ \\
\hline 1 & 11.2 .1997 & 32.3 & 214.3 & 4.5 & 59 & 48 & $\begin{array}{c}22 \text { right } \\
21 \text { left }\end{array}$ & $\mathrm{M}$ & maturing & Munida sp. (1) \\
3 & 10.10 .1997 & 29.6 & 175.1 & 4.1 & 60 & 49 & 21 & $\mathrm{M}$ & spent & empty \\
5 & 7.1 .2010 & 27.4 & 146.9 & 3.7 & 59 & 48 & 21 & $\mathrm{M}$ & $\begin{array}{c}\text { early } \\
\text { maturing }\end{array}$ & Munida rutllanti (3) \\
6 & 1.8 .2014 & 21.0 & 65.0 & 2.8 & 58 & 48 & 20 & $\mathrm{~F}$ & spent & empty \\
7 & 22.10 .2017 & 22.8 & 73.9 & 3.2 & 60 & 49 & 22 & ind. & spent/imm. & empty \\
8 & 22.10 .2017 & 24.5 & 100.7 & 3.4 & 59 & 48 & 21 & ind. & spent/imm. & Munida rutllanti (1) \\
\hline
\end{tabular}

viewed in January 2010 (i.e. after specimen no. 5 capture), August-September 2014 (after the capture of specimen no. 6) and February 2017 recognized this rockling because they caught it every once in a while. Particularly interesting is the interview with a fisherman who used to fish for blackspot seabream, Pagellus bogaraveo (Brünnich, 1768), from 1983 to 1991. In those years, he fished by bottom longline on rough grounds (often on coral banks) from 220 to 400 $m$ depth, off the Apulian coast. After fitting his gear with smaller hooks, in 1986, he hooked occasionally $G$. granti and, over five years, caught several specimens in total. Another bottom longline fisherman also reported several sporadic captures of this fish on coral banks.

\section{DISCUSSION}

This paper reports the first documented evidence of the Gaidropsarus granti presence in the Adriatic Sea. This evidence is based on multiple records: eight specimens fished over the years, from February 1997 to October 2017, from a circumscribed geographical zone of the south-western Adriatic Sea. Hence, this is the largest number of Mediterranean specimens recorded from one site.

The identification to the species $G$. granti of the herein discussed Adriatic specimens and their discrimination from the other AtlanticMediterranean rocklings are supported by both the unique body colouration pattern and the fin ray counts. The latter are in good agreement with the counts reported in the literature, which may be summarized by geographical area as follows. Atlantic (four specimens): II D = 56-60; $\mathrm{A}=48-51-52 ; \mathrm{P}=$ 20-21-22 (REGAN, 1903; SVETOVIDOV, 1973; SVETOVIDOV, 1986; BAÑÓN et al., 2002). Mediterranean (11 specimens): II $\mathrm{D}=$ 56 to $60 ; \mathrm{A}=45$ to $49 ; \mathrm{P}=20-21-22$ (ZACHARIOU-MAMALINGA, 1999; MURA \& CAU, 2003; PAIS et al., 2008; ORSI RELINI \& RELINI, 2014; present results). In particular, the fin ray counts falsifies the hypothesis by STEINDACHNER (1891), who erroneously ascribed a G. granti specimen from the Canary Islands to Gaidropsarus guttatus. In fact, the fin ray counts of the latter species are: II $\mathrm{D}=53-57$ and $\mathrm{P}=17-19$ (SVETOVIDOV, 1986); also the number of pectoral fin rays in G. granti is always higher than in G. guttulatus.

Both the maximum total length $(32.3 \mathrm{~cm})$ and the body height index (BH/TL range: 13.3$14.0 \%$, mean $=13.8 \%)$ of the Adriatic specimens fall within the range of those in the literature: TL $\max =39.0$ and $31.9 \mathrm{~cm}$ in the Atlantic Ocean (REGAN, 1903) and the Mediterranean Sea (PAIS et al., 2008), respectively (hence, the largest Adriatic specimen, which exceeds by only $4 \mathrm{~mm}$ the latter size, is the largest measured individual in the Mediterraenan); $\mathrm{BH} / \mathrm{TL}$ range: $12.1-14.7 \%$, mean $=13.6 \%$ (REGAN, 1903; BAÑÓN et al., 2002; MURA \& CAU, 2003). The discrepancy between these $\mathrm{BH} / \mathrm{TL}$ values and COLLETT's (1905) specimen BH/TL (17.7\%) is due to the fact that the latter specimen was a ripe female.

The body mass/total length regression equation, though based on a small data set $(n=6)$ 
hence preliminary, is the first to be computed for this species. Incidentally, the only other available (W, TL) datum (PAIS et al., 2008) was found to be an outlier with respect to the equation for the Adriatic specimens.

To these Adriatic documented finds, others could likely be added. Firstly, the report by BO et al. (2012), later confirmed by ANGELETTI et al. (2014), of a specimen observed and filmed by a ROV in the Bari canyon; this observation was not documented sensu BELLO et al. (2014) in neither paper. Secondly, the interviews with several fishermen witness to the capture of many more individuals off Mola di Bari. To sum up, the repeated occurrence of $G$. granti in the southwestern Adriatic Sea is a robust indication that the species is well established in this area.

The Mediterranean records of G. granti have been accompanied by the debate whether it is a native Mediterranean fish or an Atlantic one that recently entered this basin through the Gibraltar Strait. ZACHARIOU-MAMALINGA (1999), who first recorded this fish in the Mediterranean, ascribed its occurrence to an accidental transport through the Strait of Gibraltar. Along the same lines of thought were PAIS et al. (2008) as well as ZENETOS et al. (2009), TIRALONGO \& RUSSO (2015) and SPINELLI \& CASTRIOTA, pers. comm., although the latter Authors do not exclude the hypothesis that G. granti might be a rare native Mediterranean species which is expanding its population due to favourable unknown events. On the contrary, CORSINI-FOKA \& ECONOMIDIS (2007) deemed questionable the opinion that this is a colonizer from the Atlantic Ocean. Moreover, ORSI RELINI \& RELINI (2014), stated that "at present the hypothesis of a Mediterranean origin of the Azorean rockling cannot be rejected, nor can the idea that the Mediterranean population is native. The growing numbers of Mediterranean records related to the Atlantic ones reinforce this interpretation." In this respect the present official position of the "CIESM Atlas of Exotic Fishes in the Mediterranean Sea' is the same as in 2002. GOLANI et al. (2002 and subsequent updates) listed $G$. granti in the 'List of excluded species' and wrote that it is not possible at this time to determine whether this species is indigenous or exotic to the Mediterranean." In fact, both alternative suppositions have some support.

The Mediterranean autochthonous origin hypothesis is well argued by ORSI RELINI \& RELINI (2014), hence refer to it for details. A main point is that, until a few dacades ago, the fishing technology was inadequate to fish on the grounds where $G$. granti lives. Another point is the wide distribution of $G$. granti all over the Mediterranean Sea - Alboran, Tyrrhenian, Ligurian, northern Ionian, Levant and Adriatic Seas - a fact which does not comfortably agree with an ostensible quite rapid (in the order of two decades) post-immigration spreading throughout both the eastern and western Mediterranean basins. In addition, the slight dissimilarity in anal fin ray counts between Atlantic and Mediterranean specimens (see above) - average counts: $49.8(\mathrm{n}=4)$ and $47.6(\mathrm{n}=11)$ rays, respectively - might depend on morphological differences between long-separated populations, hence further support the autochthonous origin hypothesis; however, no conclusion may be drawn here due to the scantiness of the samples.

The contrasting allochthonous hypothesis is mainly based on the lack of Mediterranean records prior to its oldest documented capture in 1989 (ORSI RELINI \& RELINI, 2014), which was followed by a few finds within a short lapse of time (Fig. 1), coupled with the belief that such a conspicuous fish could not have gone unnoticed if caught before. Rough grounds that have yielded documented G. granti specimens since 1989, although somehow probed in earlier times by bottom longlines and trammel nets, produced no records of this fish until the end of the ' $80 \mathrm{~s}$, when it started to be caught by diverse gears: hooks (ORSI RELINI \& RELINI, 2014 and present results), "nets on a sandy bottom" (ZACHARIOUMAMALINGA, 1999), trawl (MURA \& CAU, 2003 and present results), trammel nets (PAIS et al., 2008) and traps (TIRALONGO \& RUSSO, 2015 and SPINELLI \& CASTRIOTA, pers. comm.). Accordingly, had this conspicuous fish inhabited the Mediterranean Sea since aeons, its presence would have been known to fishermen, and likely to marine biologists, prior to 1989. Present results appear to support the latter hypothesis, though not conclusively. Both the sudden occurrence of several specimens trawled in the south-western 
Adriatic Sea since 1997 and the congruent interviews with fishermen, who only in recent times noticed this beautiful and remarkable fish, seem to reinforce the hypothesis that G. granti entered the Mediterranean Sea just few decades ago. Incidentally, reports by south-eastern Sicilian fishermen (TIRALONGO \& RUSSO, 2015) are in line with the Adriatic fishermen.

In further support of the allochthonous hypothesis, one may mention that members of the genus Gaidropsarus reproduce by rather small planktonic eggs, $\varnothing=0.74 \mathrm{~mm}$, and have a quite long larval pelagic phase (D'ANCONA, 1931). This statement was backed by the observation that body colour had barely started to change from blue-silver, i.e. pelagic stage, to brown, i.e. benthic stage, in a $3.8 \mathrm{~cm}$ long individual (D'ANCONA, 1931). Hence, the weeks long pelagic phase of $G$. granti would be sufficient to make its eggs and/or larvae enter the Mediterranean through the Strait of Gibraltar (see also MURA \& CAU, 2003) carried by the constant inflow of Atlantic water (AW) (MILLOT \& TAUPIER-LETAGE, 2005). The large AW surface current runs all along the southern Mediterranean coasts and, at the level of the Sicilian sill, splits into the Tyrrhenian vein, which feeds the Western Basin gyre, and the southern vein, which feeds the Eastern Basin gyre, reaches the island of Rhodes hence flows along the southern Aegean islands, the eastern Ionian Sea off the continental Greek coasts and enters the Adriatic Sea (MILLOT \& TAUPIER-LETAGE, 2005). Incidentally, a large number of allochthonous fishes have entered the Adriatic Sea in the last quarter of a century (DULČIĆ \& LIPEJ, 2015). Therefore, the AW may have carried eggs and/or planktotrophic larvae to either the Western Basin or the Eastern Basin gyre - possibly by successive bouts of invasion from the Atlantic Ocean - which brought this fish to both Mediterranean basins. Taking into account a very rough overall average gyre speed of $20 \mathrm{~km} /$ day (TAUPIER-LETAGE, pers. comm.), it is likely that G. granti viable Atlantic-born eggs and larvae reached the western basin coasts, e.g. Sardinia, via current-carried plankton. By contrast, to reach the island of Rhodes it would take eggs and larvae some 150-180 days (= distance from Gibraltar Strait / ca. 20 km/day), which is indeed a too long time for their survival during the planktic phase. The best supposition is that $G$. granti should have settled somewhere along the track of the Eastern Basin gyre. Therefore, it is plausible that this fish expanded its distribution from the southern Aegean islands to the south Adriatic Sea in one generation. The allochthonous hypothesis for the Mediterranean presence of $G$. granti would be corroborated by records of its occurrence along the northern African and Asia Minor coasts and, yet more soundly, by the evidence of its establishment in the Atlantic vicinity of the Gibraltar Strait. In this respect see BAÑóN et al. (2002) about the northward expansion into the North-East Atlantic Ocean of several fish species, including $G$. granti, because of changes in North Atlantic current patterns.

In summary, presently both the allochthonous and autochthonous hypotheses have some support. Additional information is needed to shed light on the actual origin of G. granti. In particular, genetic analyses would turn useful in establishing, by the molecular clock, the time elapsed since the separation of the Mediterranean population from the Atlantic one. Furthermore, the comparison of morphological characters (e.g. anal fin ray counts) between statistically representative samples from the two populations might reveal significant differences between them. Complementary, supporting investigations might search for the size of $G$. granti mature oocytes and spawned eggs as well as for the span of its planktonic life in relation to long-distance travelling capability.

Whichever the origin of G. granti, its fairly low capture rates depend on its preferential habitat, that is rough grounds rich in hard structures, such as the cold water coral dominated system (or coral banks) in the south-western Adriatic Sea (ANGELETTI et al., 2014, with references therein), where trawling is not feasible.

With regard to the depth of occurrence of $G$. granti, PAIS et al. (2008) pointed out the discrepancy between that for the Atlantic Ocean, i.e. 20-50 m (SVETOVIDOV, 1986b), and the Mediterranean, i.e. 120-700 m (ZACHARIOU-MAMALINGA, 1999; MURA \& CAU, 2003; PAIS et al., 2008; ORSI RELINI \& RELINI, 2014; SPINELLI \& CASTRIOTA, 
pers. comm. The comparatively recent Atlantic find by BAÑÓN et al. (2002) is also deep, definitely the deepest one: $823 \mathrm{~m}$. Hence the discrepancy concerns the depth of all modern records, ranging from 120 to $823 \mathrm{~m}$ (see also GARCIA, 2015), vs. the historical ones. Indeed none of the first four finds (STEINDACHNER, 1891; REGAN, 1903; COLLETT, 1905) was accompanied by any record of capture depth. Svetovidov at first wrote "[It] Probably lives offshore in deeper waters than $G$. guttatus which is littoral and inshore in habit" (SVETOVIDOV, 1973) and later on "[it] probably lives on rough ground at 20-50 m" (SVETOVIDOV, 1986). It appears now that Svetovidov's supposition was not right.

Very little was known about the biology of this species (SVETOVIDOV, 1986). COLLETT's (1905: 726) rockling was a fully ripe female, but "the exact season when the specimen was obtained [could not] be stated." Six of the recently collected and sex-wise examined specimens were adult, four males and three females. The only mature specimen was the female collected in the northern Ionian Sea in December (SPINELLI \& CASTRIOTA, pers. comm.). Two males caught in January and February, respectively, were maturing (present results). All the others were spent: a male collected in March (PAIS et al., 2008); a male and a female collected in October and August, respectively (present results); a female collected between August and January (ORSI RELINI \& RELINI, 2014). These results are somewhat contrasting with each other, so that it is not possible now to conceive the reproductive cycle of $G$. granti in the Mediterranean Sea.

Regarding G. granti feeding, its food remains list includes: a palaemonid shrimp and some vertebrae of small fish (COLLETT, 1905), unidentified decapod natantia (PAIS et al., 2008), small decapod crustaceans to all apparences pelagic (ORSI RELINI \& RELINI, 2014) and several galatheid shrimps of the genus Munida (present results). Hence, small decapod crustaceans represent its preferential food. In particular the galatheid identified to the species level, namely Munida rutllanti (Zariquiey, 1952), colonized the Adriatic Sea in recent years (FROGLIA \& GRAMITTO, 2005; PETRIĆ et al., 2010).
Lastly, despite recent concern with the publication of an unsuspected large fraction of erroneous fish records, i.e. based on misidentifications (BELLO et al., 2014), one must point out that several Mediterranean records of G. granti have been published without any documental support. The same Adriatic record was at first reported in the "CIESM Atlas of Exotic Species in the Mediterranean" (GOLANI et al., 2002) based on a confidential communication from the present author to the senior author of that important atlas, without the production of any piece of evidence. The papers reporting a subsequent Adriatic record of this fish, observed by ROV, were also devoid of any documentation as well as any additional information (BO et al., 2012; ALLEGRETTI et al., 2014); of course, there is little doubt that the animal was correctly identified because of its unique colouration. The same is true for AGUILAR et al. (2013), who just mentioned it in a list of animals observed by ROV on Chella Bank, Alboran Sea; in this regard, I pointed out above the importance of $G$. granti findings by the Strait of Gibraltar to infer its allochthonous Mediterranean origin.

\section{ACKNOWLEDGEMENTS}

I am grateful to Mr. Ottavio Furio, who provided the first specimens of Gaidropsarus granti, Mr. Vincenzo PALAZZO and all fishermen that gave me additional specimens and/or information; among them, Mr. Rocco ARDITO for communicating blackspot seabream fishery data and Mr. Peppino DILORENZO for reporting on his bottom longline fishing activity. I would like to express my gratitude to Dr. Katia PADOVANO for assistance in collecting material and Dr. Rosa ZUPA for help in the laboratory. I also wish to thank Dr. Isabelle TAUPIER-LETAGE, who kindly read a previous version of this paper and provided useful suggestions; two anonymous referees, whose suggestions improved this paper; and Dr. Maria CORSINI-FOKA for supplying literature. Dr. Luca Castriota generously provided information and his MS in advance of its submission. Prof. Lidia ORSI RELINI is acknowledged for the beneficial exchange of opinions about the biogeography of this beautiful fish. 


\section{REFERENCES}

AGUILAR, R., X. PASTOR, S. GARCIA, P. MARIN \& J. UBERO. 2013. Importance of seamounts-like features for Mediterranean marine habitats and threatened species. Rapp. Comm. int. mer Médit., 40: 716.

ANDAlORO, F., L. CASTRIOTA, M. FALAUTANO, F. SERENA \& L. ORSI RELINI. 2011. Pesci: Gaidropsarus granti. In: AA.VV., Atlante delle specie non indigene nei mari italiani e nel Mediterraneo. Ispra. Roma: http://www. marinealien.sinanet.isprambiente.it/uploads/ Gaidropsarus\%20granti.pdf [accessed 2017, February 12].

ANGELETTI, L., M. TAVIANI, S. CANESE, F. FOGLINI, F. MASTROTOTARO, A. ARGNANI, F. TRINCARDI, T. BAKRAN-PETRICIOLI, A. CEREGATO, G. CHIMIENTI, V. MAČIĆ \& A. POLISENO. 2014. New deep-water cnidarian sites in the southern Adriatic Sea. Med. Mar. Sci., 15: 263273.

ANONYMOUS. 2014. MOTELLA delle AZZORRE [photo by Carmelo Infortuna]. In: I pesci dei mari d'Italia: http://www.colapisci.it/PescItalia/pisces/gadiformes/lotidae/Gaidropsarusgranti.htm [accessed 2017, February 12].

BAÑÓN, R., J.L. DEL RIO, C. PIÑEIRO \& M. CASAS. 2002. Occurrence of tropical affnity fish in Galician waters, north-west Spain. J. Mar. Biol. Ass. U.K., 82: 877-880.

BAÑÓN, R., D. VILLEGAS-RÍOS, A. SERRANO, G. MUCIENTES \& J.C. ARRONTE. 2010. Marine fishes from Galicia (NW Spain): an updated checklist. Zootaxa, 2667: 1-27.

BELLO, G., R. CAUSSE, L. LIPEJ \& J. DULČIĆ. 2014. A proposed best practice approach to overcome unverified and unverifiable "first records" in ichthyology. Cybium, 38: 9-14.

BELLO G. \& E. RIZZI. 1988. I teleostei raccolti nell'Adriatico meridionale nelle campagne sperimentali di pesca a strascico 1985-87. Quad. Ist. Ric. Pesca Maritt. Ancona, 5: 77-90.

BO, M., M. BERTOLino, G. BAVESTREllo, S. CANESE, M. GIUSTI, M. ANGIOLILLO, M. PANSINI \& M. TAVIANI. 2012. Role of deep sponge grounds in the Mediterranean Sea: a case study in southern Italy. Hydrobiologia, 687: 163-177.

BRITO, A., P.J. PASCAL, J.M. FALCON, A. SANCHO \& G. GONZALES. 2002. Peces de las Islas Canarias. Catalogo Comentado e Ilustrado. Francisco Lemus. La Laguna, Spain, 419 pp. COHEN, D.M., T. INADA, T. IWAMOTO \& N. SCIALABBA. 1990. FAO species catalogue. Vol. 10. Gadiform fishes of the world (Order Gadiformes). An annotated and illustrated catalogue of cods, hakes, grenadiers and other gadiform fishes known to date. FAO Fish. Synop., 125(10): 1-442.

COLLETT, R. 1905. On some fishes from the sea off the Azores. Zool. Anz., 27: 723-730.

CORSINI-FOKA, M. \& P.S. ECONOMIDIS. 2007. Allochthonous and vagrant ichthyofauna in Hellenic marine and estuarine waters. Med. Mar. Sci., 8: 67-89.

D'ANCONA, U. 1931. Clupeoidei, Heteromi, Apodi, Synentognathi e Gadidae. In: Uova, larve e stadi giovanili di Teleostei. Fauna Flora Golfo Napoli, 38(1-2).

DULČIĆ, J. \& L. LIPEJ. 2015. The current status of the Adriatic sea fish biodiversity. XV European Congress of Ichthyology. Frontiers Mar. Sci., doi: 10.3389/conf.fmars.2015.03.00073. FROGLIA, C. \& M.E. GRAMITTO. 2005. Will Munida rutllanti (Zariquiey, 1952) replace Munida intermedia (Milne Edwards \& Bouvier, 1899) (Decapoda: Galatheidae) in the central Adriatic trawling ground? 6th International Crustacean Congress, Glasgow, Scotland, 18-22 July 2005.

GARCIA, S. 2015. Gaidropsarus granti. In: The IUCN Red List of Threatened Species 2015: e.T198589A18984376. Retrieved from http://dx.doi.org/10.2305/IUCN.UK.20151.RLTS.T198589A18984376.en [accessed 2017, February 12].

GOLANI, D., L. ORSI RELINI, E. MASSUTI \& J.P. QUIGNARD. 2002 and subsequent online updates. Fishes. In: F. Briand (Editor). CIESM Atlas of Exotic Species in the Mediterranean, Vol. 1. CIESM Publisher. Monaco, pp. 1-256. Retreived from www.ciesm.org [accessed 2017, February 24]. 
HOLDEN, M.J. \& D.F.S. RAITT. 1974. Manual of Fisheries Science. Part 2. Methods of Resource Investigation and their Application. FAO Fish. Tech. Pap., 115: 1-255.

LIPEJ, L. \& J. DULČIĆ. 2010. Checklist of the Adriatic Sea Fishes. Zootaxa, 2589: 1-92.

LUNA, S.M. \& L.Q. AUGUSTIN. 2017. Gaidropsarus granti (Regan, 1903). In: R. Froese \& D. Pauly (Editors). FishBase. World Wide Web electronic publication. www.fishbase.org. (06/2017) [accessed 2017, October 16].

MENEZES, G.M., A. ROSA, O. MELO, M.R. PINHO. 2009. Demersal fish assemblages off the Seine and Sedlo seamounts (northeast Atlantic). Deep Sea Res. II, 56: 2683-2704.

Millot, C. \& I. TAUPIER-LeTAGE. 2005. Circulation in the Mediterranean Sea. Handb. Env. Chem., 5(K): 29-66.

MURA, M. \& A. CAU. 2003. Sulla presenza di Gaidropsarus granti (Regan, 1903) (Osteichthyes, Gadidae) nel Mediterraneo centro-occidentale. Biol. Mar. Medit., 10: 866-869.

ORSI RELINI, L. \& G. RELINI. 2014. Gaidropsarus granti from a Ligurian seamount: a Mediterranean native species? Mar. Ecol., 35(suppl. 1): 35-40.

PAIS, A., P. MERELLA, M.C. FOLLESA, G. GARIPPA \& D. GOLANI. 2008. New data on Gaidropsarus granti (Regan, 1903) (Gadiformes: Lotidae) from the Mediterranean Sea, with emphasis on its parasites. Sci. Mar., 72: 461-468.

PETRIĆ, M., J. FERRI \& I. MLADINEO. 2010. Growth and reproduction of Munida rutllanti (Decapoda: Anomura: Galatheidae) and impact of parasitism by Pleurocrypta sp. (Isopoda: Bopyridae) in the Adriatic Sea. J. Mar. Biol. Ass. U.K., 90: 1395-1404.

REGAN, C.T. 1903. On a collection of fishes from the Azores. Ann. Mag. Nat. Hist., 12: 346348.

RELINI, G. \& L. LANTERI. 2010. Osteichthyes. In: G. Relini (Editor). Checklist della flora e della fauna dei mari italiani. Biol. Mar. Medit., 17(suppl. 1): 649-674.
STEINDACHNER, F. 1891. Ueber einige seltene und neue Fischarte naus dem Canarischen Archipelagus. Ichthyologische Beiträge (XV). Sitzungsber. Akad. Wiss. Wien, 15: 343-361.

SVETOVIDOV, A.N. 1973. Gadidae. In: J.C. Hureau $\&$ T. Monod (Editors). Check-list of the Fishes of the North-eastern Atlantic and of the Mediterranean. UNESCO. Paris, 303-320.

SVETOVIDOV, A.N. 1986. Review of the threebearded rocklings of the genus Gaidropsaurus Refinesque, 1810 (Gadidae) with description of a new species. J. Ichthyol., 62: 115-135.

TIRALONGO, F. \& F. RUSSO. 2015. First record of Gaidropsarus granti (Regan, 1903), (Gadiformes: Lotidae), in the Ionian Sea. In: A. Zenetos, E.H.Kh. Akel, C. Apostolidis, M. Bilecenoglu, G. Bitar, V. Buchet, N. Chalari, M. Corsini-Foka, F. Crocetta, A. Dogrammatzi, M. Drakulić, G. Fanelli, G. Giglio, A. Imsiridou, K. Kapiris, P.K. Karachle, S. Kavadas, G. Kondylatos, E. Lefkaditou, L. Lipej, B. Mavrič, G. Minos, R. Moussa, E. Prato, M.A. Pancucci-Papadopoulou, W. Renda, N. Ríos, S.I. Rizkalla, F. Russo, M. Servonnat, A. Siapatis, E. Sperone, J.A. Theodorou, F. Tiralongo \& I. Tzovenis. New Mediterranean Biodiversity Records (April 2015). Med. Mar. Sci., 16: 266-284.

ZACHARIOU-MAMALINGA, H. 1999. The occurrence of the Atlantic fish Gaidropsarus granti in the Mediterranean Sea (South-Eastern Aegean Sea, Dodecanese, Greece, Eastern Mediterranean). Ann. Mus. Goulandris, 10: 261-266.

ZENETOS, A., M.A. PANCUCCI-PAPADOPOULOU, S. ZOGARIS, E. PAPASTERGIADOU, L. VARDAKAS, K. ALIGIZAKI \& A.N. ECONOMOU. 2009. Aquatic alien species in Greece (2009): tracking sources, patterns and effects on the ecosystem. J. Biol. Res. Thessaloniki, 12: 135-172.

ZARIQUIEY ALVAREZ, R. 1968. Crustáceos decápodos ibéricos. Inv. Pesq., 32: 1-510. 


\title{
Dokumentirani nalazi vrste Gaidropsarus granti (Osteichthyes: Lotidae) u Jadranskom moru i pregled njezinih pojavljivanja u Sredozemnom moru: da li se radi o autohtonoj ili novopridošloj vrsti ribe?
}

\author{
Giambattista BELLO \\ *e-pošta: giamb.bello@gmail.com
}

\begin{abstract}
SAŽETAK
Gaidropsarus granti (Osteichthyes: Lotidae) je rijetka riba koja je prvi put zabilježena u Sredozemnom moru 1989. godine. Nalazi u Sredozemnom moru su dokumentirani za Ligursko more, Levantinsko more blizu Rodosa, s obale Sardinije i sjevernije Jonsko more južno od Messine. Dodatna izvješća ukazala su na njegovu prisutnost u Alboranskom moru, u južnom Jadranu i zapadno od Malte, iako bez ikakvih dodatnih informacija. U ovom radu prikazana je pojava $G$. granti u Jadranskom moru (istočni dio Sredozemnog mora) zahvaljujući ispitivanju osam uzoraka sakupljenih u jugozapadnom dijelu, u razdoblju između veljače 1997. i listopada 2017. godine. Šest primjeraka je ulovljeno na dubinama od 190 do 290 m, uglavnom u kanalu između koraljnih grebena, dok su dva uzorka uhvaćena udicom na dubini od $420 \mathrm{~m}$ na koraljnom grebenu. Njihova ukupna duljina kretala se od 21,0 do $32,3 \mathrm{~cm}$. Četiri izdvojena primjerka su bila odrasle jedinke, tri mužjaka i jedna ženka. Želudci dvaju primjeraka su sadržavali samo rakove roda Munidae, od kojih su neki identificirani kao M. rutllanti. Sudeći po intervjuima s ribarima sa područja gdje su bili ulovljeni uzorci G. granti, ta lako prepoznatljiva riba bila je nepoznata do 1997. godine. Nakon toga, postala je uobičajena i prepoznata od strane ribara jer se od tada sporadično lovi. Vode se rasprave o tome da li je G. granti autohtona sredozemna vrsta ili novopridošla vrsta koja je tu dospjela prije nekoliko desetljeća. Obje hipoteze imaju uporište.

Hipoteza o autohtonom podrijetlu uglavnom se temelji na zastupljenosti G. granti diljem Sredozemlja i relativne nedostupnosti starijim ribolovnim alatima neadekvatnim za ribolov na dubokim i grubim terenima. Oprečnu hipotezu podupire potpuni nedostatak nalaza u Sredozemnom moru prije 1989. godine zajedno s prilično dugom larvalnom pelagičkom fazom.
\end{abstract}

Ključne riječi: Gaidropsarus granti, Lotidae, Jadransko more, Sredozemlje, novi nalazi 
